\title{
Allelopathyc potential of baccharis salicifolia against staphylococcus aureus
}

\begin{abstract}
Baccharis salicifolia is a species that has been shown to have significant bioactivities; several species of this genus are used in the popular medicine like diuretic, digestive and antifungal; however, there are few studies on the composition and active compounds of Baccharis. Allelopathic potential of ethanolic fractions of $B$. salicifolia was evaluated on antimicrobial activity against Staphylococcus aureus. The antibacterial activity of the $B$. salicifolia ethanolic extract on S. aureus was evaluated by the disc method and the bioguide fractionation by Thin Layer Chromatography (CCF) and Chromatography in Column (CC). The results showed that inhibition exists in the various fractions of the ethanolic extract (between $50-80 \%$ respectively) with respect to the positive control; The fractionation by $\mathrm{CCF}$ and with $\mathrm{CC}$, allowed to evaluate 10 ethanolic fractions which possess the metabolites responsible for the antibacterial activity on $S$. aureus.
\end{abstract}

Keywords: antibacterial activity, Baccharis salicifolia, ethanolic extract, Staphylococcus aureus
Volume 2 Issue 5 - 2018

\author{
Sandra Luz Cabrera Hilerio, Eduardo Javier \\ Escalante Hernández, Mariana Miranda \\ Arámbula \\ Dept. of Biochemistry-Food,Autonomous University of Puebla, \\ Mexico
}

\begin{abstract}
Correspondence: Sandra Luz Cabrera-Hilerio, Faculty. of Chemical Sciences, Dept. of Biochemistry-Food, Benemérita, Autonomous University of Puebla, University City, Av. San Claudio and I4 Sur, Col. San Manuel, C.P. 72570 Puebla, Mexico, Email cabrerahilerio_sl@hotmail.com
\end{abstract}

Received: September 02, 2017 | Published: October 05, 2018

\section{Introduction}

Allelopathic plants are known to produce compounds that may influence stimulating or inhibiting different biological processes of other organisms. ${ }^{1}$ It has been suggested that allelopathy is an important factor in regulating the structure of plant communities and the speed of growth of plants in the field. ${ }^{2}$ This allelopathic function has been attributed to several flavonoids, phenolic and terpenoid structures. ${ }^{3}$ The allelopathic potential of plants can be used as a bactericide, fungicide, herbicide, insecticide, among others; and one of the applications that have taken relevance in recent years is the use of compounds from these plants for the control of foodborne diseases. ${ }^{4}$ A large variety of microorganisms can lead to food spoilage including Escherichia coli, Klebsiella pneumoniae, Listeria monocytogenes, Salmonella sp, Bacillus cereus and Staphylococcus aureus. ${ }^{5,6}$ Some plant species with allelopathic properties have shown, through different extracts, activity against enteropathogenic organisms. Some plant extracts prove to be an alternative for the control of pathogenic bacteria with resistance to conventional drugs. ${ }^{7}$

Baccharis salicifolia L. is a member of the Asteraceae family and has several species that have already been reported in the treatment of some human diseases in traditional medicine. ${ }^{8}$ Studies accomplished on the chemical composition of different species of the genus, shown the presence of numerous secondary metabolites such as diterpenoids and flavonoids. ${ }^{9}$ In the present work, the fractions of the ethanolic extract of Baccharis salicifolia were evaluated for allelopathic potential and its effect against $S$. aureus microorganism. Chromatographic fractions were obtained from conventional methods of separation of chemical compounds such as thin layer chromatography (TLC) and column chromatography $(\mathrm{CC})$.

\section{Methodology}

The extract was obtained from $10 \mathrm{~g}$ of dry and ground B. salicifolia leaves with $125 \mathrm{ml}$ ethanol in a soxhlet apparatus for $5 \mathrm{~h}$. Subsequently it was evaporated to dryness using a vacuum rotary evaporator and the sample was stored in amber flasks at $-20^{\circ} \mathrm{C}$. The ethanolic extract was fractionated by column chromatography (CC) with 35-70 mesh silica gel $(210.7560 \mathrm{~g})$, on a $2.5 \times 10 \mathrm{~cm}$ column. The solvent system used was of ascending polarity: chloroform, ethyl acetate and acetone, (1:1:1). The total of fractions collected were 10 which were enumerated from 1 to 10 . Obtained fractions were stored at low temperatures. ${ }^{10}$

\section{Evaluation of antibacterial activity}

Bacterial strain Staphylococcus aureus (strain 921) isolated was obtained from the collection of the Microbiology Department of the Chemical Sciences Faculty of Universidad Autonoma de Puebla (BUAP), Mexico. Antibacterial activity of the fractions was evaluated using the disc method, for which the strain was inoculated at a concentration of $1.5 \times 10^{8} \mathrm{cells} / \mathrm{mL}$, corresponding to tube 0.5 of McFarland Nephelometer. Mueller Hinton agar plates were placed on Whatman\#3 filter paper with $20 \mu \mathrm{L}$ of each fraction, using Vancomycin as positive control and two negative controls, sterile water and solvent. Plates were incubated at $37^{\circ} \mathrm{C}$ for $24 \mathrm{~h}$, and size of the inhibition halos was measured after this time. To determine the inhibition percent, the was that applied by Martinez. ${ }^{11}$ At least three repetitions were run for each assay.

\section{Results and discussion}

The results of the biological activity of ethanolic extract fractions against $S$. aureus are reported in Figure 1, where it can be observed that the first four fractions $(1,2,3$, and 4$)$ did not show inhibition activity on the microorganism at $24 \mathrm{~h}$. However, the following fractions (5 to 10) have antibacterial activity in the different percentages ranging from $52.5-85 \%$. Fraction 10 showed the highest bioactivity of inhibition $(85 \%)$ on the target organism, compared to the other fractions 5-9 and the control treatment (conventional chemical bactericide). This shows that the fractions with higher polarity present greater bactericidal activity, which indicates the presence of possible biologically active polar compounds of $B$. salicifolia against $S$. aureus microorganism. The results obtained are correlated with previous studies, which also demonstrate the antibacterial activity of B. salicifolia on Staphylococcus aureus. ${ }^{12}$ However, Carrizo et al. ${ }^{5}$ shows that oily extracts of B. salicifolia had activity on Staphylococcus aureus, Listeria monocytogenes and Bacillus cereus. This diverse activity 
in the extracts can be due to the diverse chemical compounds that have been found and analyzed in some species of the genus Baccharis like B. glutinosa, B. salicifolia and B. genistelloides, emphasizing the presence of flavonoids, terpenes and steroids, substances reductants, lactones and coumarins. The metabolites present in the genus Baccharis that have been attributed with various biological activities and properties are mainly flavonoids of the flavanone and flavone type; the kaurane nucleus diterpenes, cleorodans and labdano. ${ }^{13}$

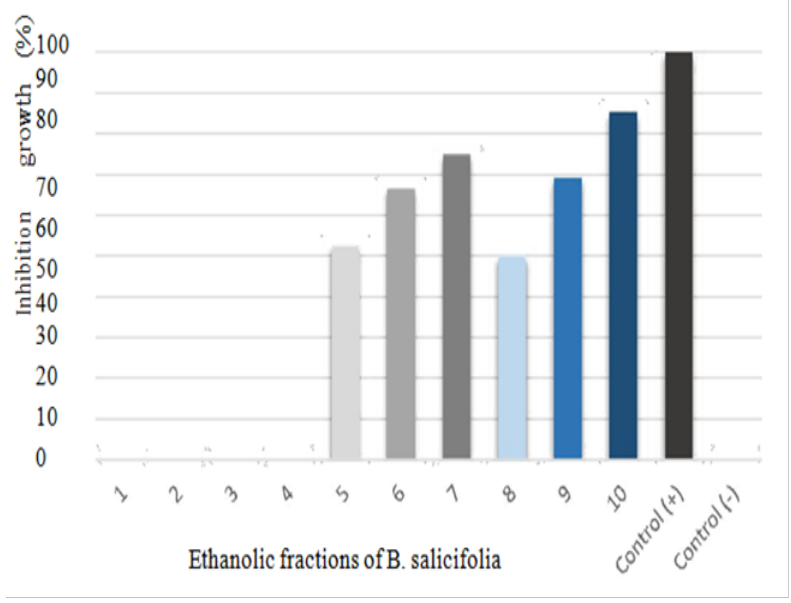

Figure I Percentage inhibition of the antibacterial activity of the various ethanolic extract fractions of B. salicifolia against S. aureus at $24 \mathrm{~h}$.

In B. salicifolia at least five flavonoids have been isolated in organic extracts with methylene chloride. ${ }^{14}$ Analyzing the chromatographic profiles obtained in this work, we consider that these types of compounds are responsible for the antibacterial activity. According to our results, B. salicifolia possesses the potential to inhibit the growth of resistant microorganisms overcoming the effect of some conventional drugs.

\section{Conclusion}

Ethanolic fractions obtained from Baccharis salicifolia report antibacterial activity, finding that the fraction 10 was the one of greater growth inhibition activity against $S$. aureus, compared to the positive control treatment. These data demonstrate that it would be interesting for future investigations the discovery of new allelopathic compounds with antibacterial potential.

\section{Acknowledgments}

None.

\section{Conflict of interest}

The authors declare there is no conflict of interest.

\section{References}

1. Farooq M, Jabran K, Cheema ZA, et al. The role of allelopathy in agricultural pest management. Pest Management Science. 2011;67(5):493-506.

2. Wardle DA, Nicholson KS, Rahman A. Use of a comparative approach to identify allelopathic potential and relationship between allelopathy bioassays and competition experiments for ten grassland and plant species. J Chem Ecol. 1996;22(5):933-948.

3. Withaker RH, Feeny PP. Allelochemics: Chemical interactions between species. Science. 1971;171(3973):757-770.

4. Jabran K, Mahajan G, Sardana V, et al. Allelopathy for weed control in agricultural systems. Crop Protection. 2015;72:57-65.

5. Carrizo FR, Ponzi M, Ardanaz C, et al. Chemical composition of essential oil of Baccharis salicifolia (Ruiz \& Pavon) Pers. and antibacterial activity. J Chil Chem Soc. 2009;54(4):475-476.

6. Sauceda ENR. Uso de agentes antimicrobianos naturales en la conservación de frutas y hortalizas. Ra Ximhai. 2011;7(1):153-170.

7. Zamorano C. Alelopatía: un nuevo reto en la ciencia de las arvenses en el trópico. Agron, 2006;14(1):7-15.

8. Madeira FP. Flavonoides e Triterpenos de Baccharis pseudo tenuifoliaBioactividades sobre Artemia salina. Quim Nova. 2003;26(3):309-311.

9. Gianello J, Giordano O. Examen químico en seis especies del género Baccharis. Rev. Lat. de Química. 1984;15:81-86.

10. Knowles JR, Roller S, Murray DB, et al. Antimicrobial action of carvacrol at different stages of dual-species biofilm development by Staphylococcus aureus and Salmonella enterica serovar Typhimurium. Appl Environ Microbiol, 2005;71(2):797-803.

11. Martínez MJ. Ausencia de actividad antimicrobiana de un extracto acuoso liofilizado de Aloe vera (sábila). Rev Cubana Plant Med, 1996;1(3):18-20.

12. Bussmann RW, Ashley G, Sharon D, et al. Proving that traditional knowledge works the antibacterial activity of Northern Peruvian medicinal plants. Ethnobotany Research and Applications. 2011;9:67-96.

13. Verdi LG, Brighente IMC, Pizzolatti MG. Gênero Baccharis (Asteraceae): aspectos químicos, econômicos e biológicos. Quím Nova. 2005;28(1):85-94.

14. Domínguez LM. Comparación de la Actividad Herbicida de dos especies de la Familia Asteraceae. En Tesis. Facultad de Química, Universidad Nacional Autónoma de México. 2002; 96 p. 